\section{Case Reports in Acute Medicine}

Case Rep Acute Med 2020;3:40-45

DOI: 10.1159/000509014

Published online: August 25, 2020
(C) 2020 The Author(s)

Published by S. Karger AG, Basel www.karger.com/cra

This article is licensed under the Creative Commons Attribution-NonCommercial 4.0 International License (CC BY-NC) (http://www.karger.com/Services/OpenAccessLicense). Usage and distribution for commercial purposes requires written permission.

\title{
Gastric Antral Vascular Ectasia Associated with Asymptomatic Mixed Connective Tissue Disease Refractory to Endoscopic Treatment: A Rare Case
}

\author{
Muhammed Jasim Abdul Jalal $^{a} \quad$ K.M. Mohammed Iqbal ${ }^{a}$ \\ Roy J. Mukkada ${ }^{b}$ Rashmi Ratnakaran ${ }^{c}$ Shani Basheer ${ }^{a}$ \\ aDepartment of Internal Medicine and Rheumatology, VPS Lakeshore Hospital, \\ Kochi, India; 'Department of Medical Gastroenterology, VPS Lakeshore Hospital, \\ Kochi, India; 'Department of Pathology, VPS Lakeshore Hospital, Kochi, India
}

\section{Keywords}

Watermelon stomach · Gastric antral vascular ectasia · Gastrointestinal bleeding · Mixed connective tissue disease $\cdot$ Endoscopy

\begin{abstract}
Gastric antral vascular ectasia (GAVE) constitutes $4 \%$ of all nonvariceal upper Gl bleedings. It is characterized by the presence of erythematous or hemorrhagic ectatic vessels within the antrum that are distributed either in a striped or diffuse punctate pattern. We report a 64-yearold female without any co-morbidities, who presented with multiple episodes of blood in stools. Laboratory studies revealed a hemoglobin level of $5 \mathrm{~g} / \mathrm{dL}$ with a hematocrit of $18.3 \%$. Iron studies revealed a serum iron level of $35 \mu \mathrm{g} / \mathrm{dL}$. She underwent an upper $\mathrm{Gl}$ endoscopy, and biopsy was consistent with gastric antral vascular ectasia. ANA (antinuclear antibody), RA (rheumatoid factor), and anti-centromere antibody were all strongly positive. Erythrocyte sedimentation rate was 56 . She was asymptomatic as far as connective tissue disease was concerned. Her anemia improved, but argon plasma coagulation failed to sustain the suppression of GAVE, and she required a blood transfusion for severe anemia on two occasions. With regard to recurrent episodes of melena, she was started on oral methyl prednisolone in a
\end{abstract}


tapering dosage. She improved with medications, and her hemoglobin is maintained at 11.3 $\mathrm{g} / \mathrm{dL}$. This is the first unique case of GAVE in a patient without any other systemic illness or portal hypertension refractory to endoscopic treatment responding to monotherapy with corticosteroids.

(c) 2020 The Author(s)

Published by S. Karger AG, Basel

\section{Introduction}

Gastric antral vascular ectasia (GAVE) presents as upper gastrointestinal (GI) bleeding. It is seen in $4 \%$ of all nonvariceal upper GI bleedings. It also occurs as a manifestation of iron deficiency anemia [1]. It is characterized by the presence of erythematous or hemorrhagic ectatic vessels within the antrum that are distributed either in a striped or diffuse punctate pattern. We report a case of GAVE in an asymptomatic mixed connective tissue disease patient. This is the first unique case of GAVE in a patient without any other systemic illness or portal hypertension refractory to endoscopic treatment responding to monotherapy with corticosteroids.

\section{Case Presentation}

A 64-year-old female presented with multiple episodes of blood in stools. She denied any chest pain, dyspnea, or palpitations. She was not diabetic, hypertensive, or did have any thyroid illness. There was no history of any joint pains, skin lesions, recurrent urinary tract infections, and oral/genital ulcers. The patient reported a history of chikungunya. Her vital signs showed a temperature of $97.7^{\circ} \mathrm{F}$, pulse 90 beats $/ \mathrm{min}$, respiratory rate 18 breaths $/ \mathrm{min}$, and blood pressure 140/70 mm Hg. Physical examination did not reveal any pallor, icterus, cyanosis, clubbing, lymphadenopathy, or edema. Systemic examination was unremarkable. There was no synovitis in any of the joints. No skin thickening or dryness of the skin was present.

Laboratory studies revealed a hemoglobin level of $5 \mathrm{~g} / \mathrm{dL}$ (reference range 11.7-15.5) with a hematocrit of $18.3 \%$ (reference range 35-46). Platelet count was normal at $252 \times$ $10^{3} / \mu \mathrm{L}$. Iron studies revealed a serum iron level of $35 \mu \mathrm{g} / \mathrm{dL}$ (reference range 50-170) with a total iron-binding capacity of $270 \mu \mathrm{g} / \mathrm{dL}$ (reference range 250-425). Ferritin level was 13 $\mathrm{ng} / \mathrm{mL}$ (reference range 15-150). The patient received two units of packed red blood cell transfusion, and her hematocrit was closely monitored. Liver function and renal functions were within normal limits (total bilirubin $0.8 \mathrm{mg} / \mathrm{dL}$, SGOT $25 \mathrm{U} / \mathrm{L}$, SGPT $30 \mathrm{U} / \mathrm{L}$, alkaline phosphatase $84 \mathrm{IU} / \mathrm{L}$, creatinine $0.9 \mathrm{mg} / \mathrm{dL}$ ).

She underwent an upper GI endoscopy, which showed areas of hyperemic streaks alternating with normal-appearing mucosa in the antrum, consistent with "watermelon stomach" (Fig. 1). A biopsy was obtained. Endoscopy specimen was negative for Helicobacter pylori infection. The bleeding sites responded well to banding. The hemoglobin remained stable after the procedure. The gastric antral biopsy showed a dilated capillary containing fibrin thrombus (Fig. 2) and gastric antral mucosa with foveolar hyperplasia and dilated capillaries in the lamina propria (Fig. 3).

She was worked up for any connective tissue disease. ANA (antinuclear antibody [5.6 U normal $<1]$ ), RA (rheumatoid factor $[40 \mathrm{IU} / \mathrm{mL}$ - normal $<20$ ]), anti-centromere antibody (4 $\mathrm{U}-$ normal $<1$ ), and U1-RNP antibody (30 $\mathrm{U}-$ normal $<25$ ) were all strongly positive. AntidsDNA was negative. Erythrocyte sedimentation rate was 56 . Her complement levels were low (C3 0.569 g/L [reference range 0.89-1.87]; C4 $0.106 \mathrm{~g} / \mathrm{L}$ [reference range 0.17-0.38]). 
However, she did not have any clinical features of systemic lupus, rheumatoid arthritis, or systemic sclerosis. She was asymptomatic as far as connective tissue disease was concerned.

Over an 8-month follow-up period, the patient was treated with two sessions of argon plasma coagulation (APC). Her anemia improved, but APC failed to sustain the suppression of GAVE, and she required a blood transfusion for severe anemia on two occasions. With regard to recurrent episodes of melena, she was started on methyl prednisolone in a tapering dosage (oral methyl prednisolone $16 \mathrm{mg}$ once daily for 2 weeks, followed by $12 \mathrm{mg}$ for 2 weeks, followed by $8 \mathrm{mg}$ for 2 weeks tapered to $6 \mathrm{mg}$ for 2 months). She improved with medications, and her hemoglobin is maintained at $11.3 \mathrm{~g} / \mathrm{dL}$.

\section{Discussion}

Gastric antral vascular ectasia (GAVE) was first reported in 1953 by Rider et al. [2] in an elderly female patient with chronic iron deficiency anemia. The endoscopic appearance resembled the stripes on a watermelon, and Jabbari et al. [3] in 1984 coined the term "watermelon stomach". GAVE is usually associated with underlying chronic illnesses such as cirrhosis [4]. Among patients without cirrhosis, GAVE is usually associated with underlying autoimmune connective tissue disorder, particularly Raynaud's phenomenon [5].

The pathology of GAVE still remains unclear. The various postulates include mechanical stress, altered hemodynamics, and autoimmune factors [6]. Antinuclear antibodies and anticentromere antibodies may be present in patients with GAVE.

Antral motility time is significantly increased in patients with GAVE. Peristaltic waves of loosely attached antral mucosa draw the mucosa in longitudinal folds and induce fibromuscular proliferation and secondary formation of ecstatic vessels. Histological hallmarks of GAVE are the fibromuscular proliferation and capillary ectasia with microvascular thrombosis of the lamina propria [1].

The endoscopic pattern shows longitudinal flat rows, reddish stripes diverging from the pylorus into the antrum, or a diffuse pattern of small spots in the antrum [2]. Reddish stripes diverging from the pylorus to the antrum resemble the stripes of a watermelon. Moderate to severe gastritis and portal hypertensive gastropathy are the other differential diagnosis [2].

Antrectomy is the definitive therapy for GAVE, but the mortality rate is high [6]. APC should be considered in GAVE-related bleeding, as it is the current treatment of choice for GAVE [7]. The most effective pharmacological treatments include corticosteroids, cyclophosphamide, thalidomide, tranexamic acid, interferon-alpha, calcitonin, cyproheptadine, and estrogen/progesterone [8]. Corticosteroids have been used to treat GAVE, but there are no reports on the use of corticosteroids as a single agent [1].

\section{Statement of Ethics}

The authors state that the patient reported in our manuscript have given a written informed consent to publish this case (including publication of images).

\section{Conflict of Interest Statement}

The authors have no conflicts of interest relevant to this article to declare. 


\section{Case Reports in Acute Medicine}

\begin{tabular}{l|l}
\hline Case Rep Acute Med 2020;3:40-45 \\
\hline DOI: 10.1159/000509014 & $\begin{array}{l}\text { @ 2020 The Author(s). Published by S. Karger AG, Basel } \\
\text { www.karger.com/cra }\end{array}$ \\
\hline
\end{tabular}

Abdul Jalal et al.: Gastric Antral Vascular Ectasia

\section{Funding Sources}

The authors have no financial relationships relevant to this article to disclose.

\section{Author Contributions}

Muhammed Jasim Abdul Jalal was involved with substantial contributions to the design of the work, analysis and interpretation of data for the work, drafting the work, and revising it critically for important intellectual content.

K.M. Mohammed Iqbal was involved with the analysis and interpretation of data for the work, revising it critically for important intellectual content, and giving final approval of the version to be published.

Roy J. Mukkada, Rashmi Ratnakaran, and Shani Basheer were involved with the analysis and interpretation of data for the work.

All authors are in agreement to be accountable for all aspects of the work in ensuring that questions related to the accuracy or integrity of any part of the work are appropriately investigated and resolved.

\section{References}

1 Kar P, Mitra S, Resnick JM, Torbey CF. Gastric antral vascular ectasia: case report and review of the literature. Clin Med Res. 2013 Jun;11(2):80-5.

2 Rider JA, Klotz AP, Kirsner JB. Gastritis with veno-capillary ectasia as a source of massive gastric hemorrhage. Gastroenterology. 1953 May;24(1):118-23.

3 Jabbari M, Cherry R, Lough JO, Daly DS, Kinnear DG, Goresky CA. Gastric antral vascular ectasia: the watermelon stomach. Gastroenterology. 1984 Nov;87(5):1165-70.

4 Ward EM, Raimondo M, Rosser BG, Wallace MB, Dickson RD. Prevalence and natural history of gastric antral vascular ectasia in patients undergoing orthotopic liver transplantation. J Clin Gastroenterol. 2004 NovDec;38(10):898-900.

5 Gostout CJ, Viggiano TR, Ahlquist DA, Wang KK, Larson MV, Balm R. The clinical and endoscopic spectrum of the watermelon stomach. J Clin Gastroenterol. 1992 Oct;15(3):256-63.

6 Selinger CP, Ang YS. Gastric antral vascular ectasia (GAVE): an update on clinical presentation, pathophysiology and treatment. Digestion. 2008;77(2):131-7.

7 Zepeda-Gómez S. Endoscopic treatment for gastric antral vascular ectasia: current options. GE Port J Gastroenterol. 2017 Jul;24(4):176-82.

8 Matsumoto Y, Hayashi H, Tahara K, Yasuda T, Tsubouchi S, Yamamoto Y, et al. Intravenous Cyclophosphamide for Gastric Antral Vascular Ectasia Associated with Systemic Sclerosis Refractory to Endoscopic Treatment: A Case Report and Review of the Pertinent Literature. Intern Med. 2019 Jan;58(1):135-9. 
Case Reports in Acute Medicine
Case Rep Acute Med 2020;3:40-45

DOI: $10.1159 / 000509014$

(c) www.karger.com/cra

Abdul Jalal et al.: Gastric Antral Vascular Ectasia

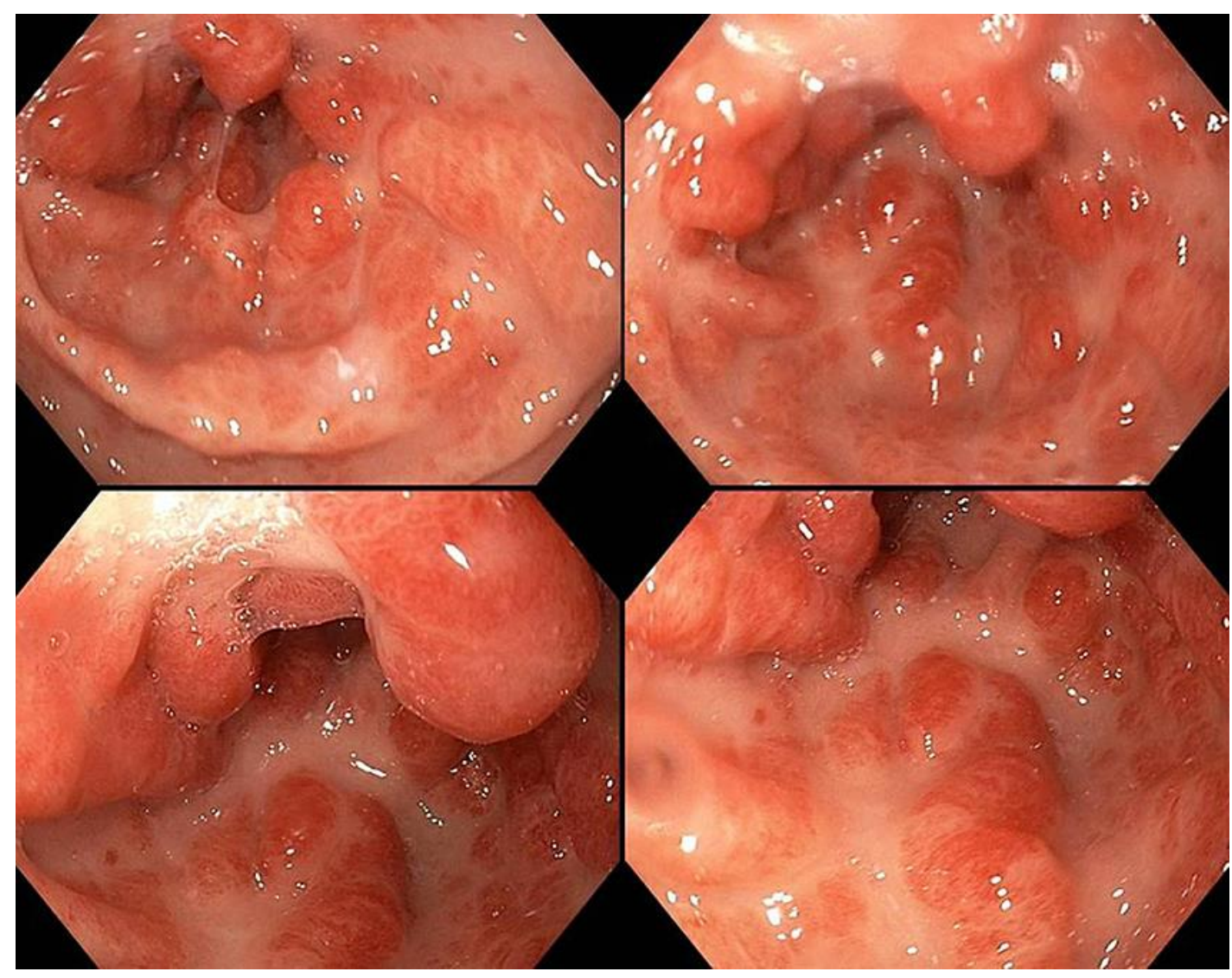

Fig. 1. Upper GI endoscopy showing areas of hyperemic streaks alternating with normal-appearing mucosa in the antrum, consistent with "watermelon stomach."

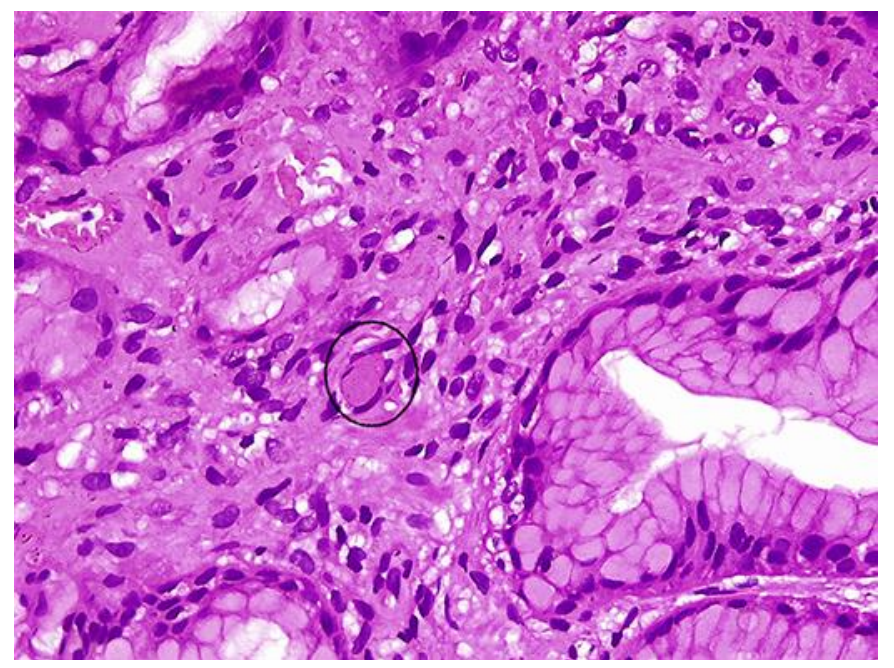

Fig. 2. High-power view showing a dilated capillary containing fibrin thrombus. 
Case Reports in Acute Medicine
Case Rep Acute Med 2020;3:40-45 DOI: 10.1159/000509014

(c) 2020 The Author(s). Published by S. Karger AG, Basel www.karger.com/cra

Abdul Jalal et al.: Gastric Antral Vascular Ectasia

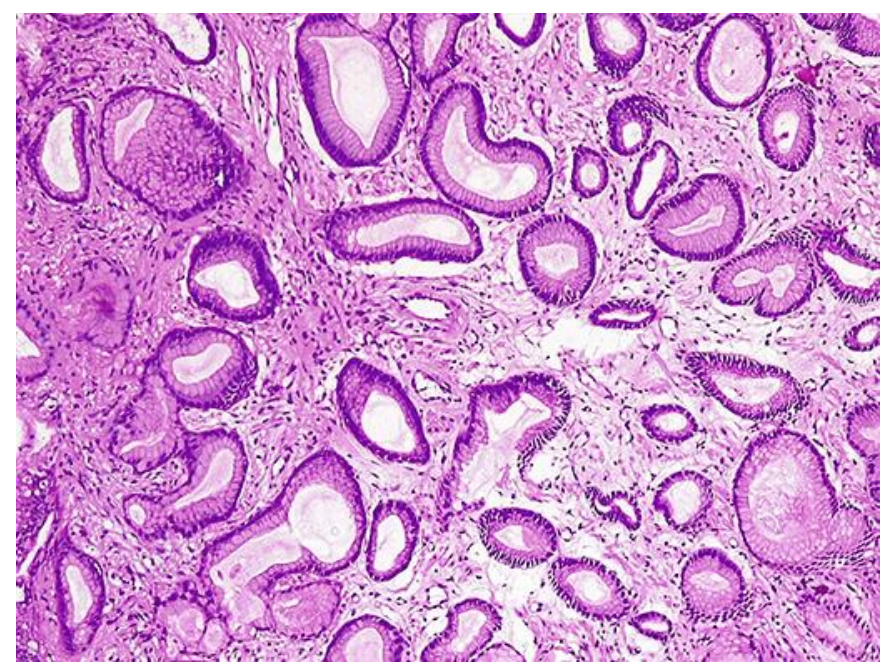

Fig. 3. Low-power view showing gastric antral mucosa with foveolar hyperplasia and dilated capillaries in the lamina propria. 